\title{
2020 top trends in academic libraries A review of the trends and issues affecting academic libraries
} in higher education

$\mathbf{T}$ his article summarizes trending topics in academic librarianship from the past two years. These highlights provide a starting point or an update, depending on one's familiarity with the topic. Overarching themes across the profession continue to emphasize the significant amount of change our institutions are driving, managing, and navigating.

\section{Change management: New skills for new leadership}

A recent Association of Research Libraries report focuses on managing change in libraries and states that there are ". . . three categories of urgent changes: changes in the research library relationship with institutional partners, changes in the research library organization, and changes in skills." The urgency described in this report indicates a need for preparing a workforce for uncertainty and ambiguity. A 2017 Library Journal article encourages new skills for library leaders to manage change in a VUCA (Volatility, Uncertainty, Complexity, and Ambiguity) world and a need to "get it right." 2

Managing change on this scale requires academic library leadership to be steeped in best practices for systematically adjusting the work of an entire organization. If our libraries are going to be successful in a VUCA world, current and future leaders will need to develop their change management skills. There are a number of leadership courses, workshops, and residential programs, and those which focus on these needed skills will be of greatest use to leaders looking to move their libraries into the future quickly and confidently.

\section{Evolving integrated library systems}

In December 2019, Ex Libris announced a deal to purchase Innovative. ${ }^{3}$ Questions immediately arose among Innovative's customers, wondering how and when this might affect them. Innovative provides a

Members of the ACRL Research Planning and Review Committee: Allison Benedetti (chair) is director of the Arts, Music, and Powell Libraries at UCLA, email: abenedetti@library.ucla.edu, Ginny Boehme (vice-chair) is science librarian at Miami University, email: boehmemv@miamioh.edu, Thomas R. Caswell is associate dean at University of North Florida, email: t.caswell@unf.edu, Kyle Denlinger is digital pedagogy and open education librarian at Wake Forest University, email: denlinkd@wfu. edu, Yuan Li is scholarly communications librarian at Princeton University, email: yl7@princeton. edu, Alex D. McAllister is humanities librarian at Appalachian State University, email: mcallisterad@ appstate.edu, Brian D. Quigley is head of the Engineering and Physical Sciences Division at the University of California-Berkeley, email: bquigley@ berkeley.edu, Catherine B. Soehner is associate dean for research and director of the Eccles Health Sciences Library and director of the MidContinental Region and Training Office, National Network of Libraries of Medicine at the University of Utah, email: email: catherine.soehner@utah.edu, Minglu Wang is research data management librarian at York University, email: mingluwa@yorku.ca, Andrew J. Wesolek is director of digital scholarship and communications at Vanderbilt University, email: andrew.j.wesolek@vanderbilt.edu 
number of integrated library system (ILS) products, including Sierra and Polaris, but its saturation of the ILS market for academic libraries is relatively low compared to its market share within public library systems. In contrast, Ex Libris controls a much larger market share within academic libraries, primarily thanks to Alma, its cloud-based library management system (LMS). Ex Libris is likely to focus its near-future efforts on transitioning and expanding its public library business to cloud-based systems, rather than making immediate large-scale changes within its academic library business. ${ }^{4}$

Large mergers like this tend to reignite concerns of interoperability between all the different systems, platforms, and devices that now comprise modern library systems. The Future Of Libraries Is Open (FOLIO) is one of the products aiming to quell those concerns, with beta testing well underway and a general release planned for $2020.5^{5}$ FOLIO is an open-source LMS being built around the idea of flexibility, with different modules available (and interchangeable) depending on need. It seems the National Information Standards Organization (NISO) is preparing for further development along these lines with the FASTEN document. ${ }^{6}$ The FASTEN document was posted for public comments during Q4 2019, and contains recommendations for vendors and organizations on steps they can take to streamline and improve the interoperability of their library systems. The wider launch of FOLIO and the potential adoption of FASTEN will need to be closely watched.

The goals driving the development of both FOLIO and FASTEN are touched on in a recent issue brief by the Ohio Library and Information Network (OhioLINK) and Ithaka S+R. ${ }^{7}$ However, the document quickly moves past them to look even further ahead. It describes the challenges seen with current ILS products and imagines what the ILS of the future should be, highlighting four qualities and recommendations: true "next-generation" systems should be user- centered, enable the use and access of facilitated collections, integrate with other institutional platforms, and provide modern business intelligence capabilities.

\section{Learning analytics}

ACRL's "2018 Top Trends in Academic Libraries" report identified the use of learning analytics (LA) as an emerging trend. ${ }^{8}$ LA advocates argue that by collecting and analyzing student learning data, including data related to library usage, institutions can better understand student learning behaviors, intervene when problems arise, and potentially even predict problems before they occur. Libraries are becoming increasingly interested in how they might use LA to communicate their value to stakeholders. ${ }^{9}$

While this trend continues, criticism of the use of library learning analytics has grown significantly since the previous "Top Trends" report. Many academic librarians are growing ever more skeptical of the value of LA, especially as their use relates to student privacy, student agency, library ethics, and student trust in libraries as institutions. ${ }^{10}$ The Data Doubles project seeks to "study library LA and the privacy issues from a student perspective," which, the research team explains, is lacking from the conversation. ${ }^{11}$ Additionally, the summer 2019 issue of Library Trends was devoted exclusively to the question of LA in libraries. As the profession continues to wrestle with the "ethical dissonance" of LA, "growing evidence suggests that learning analytics should not be pursued without carefully considering and attending to the ethical quandaries and information policy challenges stemming from the inherent student privacy issues." 12

\section{Machine learning and Al}

As is the case with many professions, librarianship is on the cusp of dramatic change owing to developments in machine learning and artificial intelligence (AI). Libraries and librarians have a long history of incorporating new technologies into their 
spaces and practices. Two reports published in 2019 call on us to act now to ensure that our professional values are "baked in" to new computational tools and research support services.

In his 2019 Library Technology Report, Jason Griffey argues that libraries should invest in developing these systems internally. ${ }^{13} \mathrm{AI}$ and machine learning are powerful tools, but without care they may manifest algorithmic bias, erode privacy and intellectual freedom, and potentially enhance confirmation bias and information filtering of the sort present in contemporary media. Griffey argues that localized machine learning and AI environments (i.e., those developed internally) allow libraries to critically examine training data and computational processes to ensure that bias present in data is not amplified through those processes, and professional values are represented in data collection and computational processes. The report also contains several examples of what library investment in these areas could look like.

An OCLC report, Responsible Operations, explores potential impacts of machine learning and AI across librarianship, as well as recommendations for guiding their adoption in responsible ways. Beyond the substantial recommendations for technical infrastructure and strategies in cultural heritage, metadata creation, and other venues, libraries should "consider using information literacy instruction as a vector to introduce algorithmic concepts and their ethical implications." ${ }^{14}$ Data and programming literacies are increasingly important for contemporary students, and libraries are gradually integrating them into their pedagogy. ${ }^{15}$ As librarians continue to explore the uses and potential misuses of $\mathrm{AI}$ and machine learning environments, there are opportunities to expand curricula focused on literacies to include ethical considerations in $\mathrm{AI}$ and machine learning.

\section{Open access: Transitions and transformations}

The past few years have brought major developments in the OA landscape-from major big deal cancellations to new agreements between libraries and publishers. Following the University of California system's Elsevier cancellation in early 2019, ${ }^{16}$ the University of North Carolina announced in late 2019 that their license renewal negotiations with Elsevier will continue into 2020. ${ }^{17}$ Resources for institutions considering this route include SPARC's "Big Deal Knowledge Base and Big Deal Cancellation Tracking," 18 University of California's "Negotiating with Scholarly Journal Publishers Toolkit," "Guidelines for Evaluating Transformative Open Access Agreements," ${ }^{20}$ and "Guide to Transitioning Journals to Open Access Publishing." ${ }^{11}$

Many new transformative agreements were announced between publishers and libraries or library consortia over the past year. ${ }^{22}$ A transformative agreement can be defined as a contract seeking "to shift the contracted payment from a library or group of libraries to a publisher away from subscription-based reading and towards open access publishing." ${ }^{23}$ There are various flavors, including offsetting agreements, read-and-publish agreements, and publishand-read agreements. Since 2018, many read-and-publish agreements have been signed between publishers and institutions.

After hundreds of responses from publishers, academic libraries, and researchers, cOALition S made some changes to its Plan $S$, which "aims for full and immediate Open Access to peer-reviewed scholarly publications from research funded by public and private grants." ${ }^{24}$ Noteworthy differences: plan implementation is delayed to 2021, no cap on the cost of OA publication, tweaked rules around hybrid titles and transformative agreements, ignore the prestige of journals when making funding decisions, and more restrictive open licenses will be allowed when approved by the funder. ${ }^{25}$

Further transitions are happening at the society publishing level. The group Transitioning Society Publications to Open Access (TSPOA) formed at the October 2018 Choosing Pathways to OA Working forum. 
They "aim to provide relevant resources/ experience working in collaboration with society publishing partners to help them develop an open access publishing model that is appropriate, effective and sustainable." ${ }^{26}$

\section{Research Data Services (RDS): Ethics and maturation}

In recent years, conversations about research data management have transitioned. While open data faces obstacles in health science and social science research, ${ }^{27}$ since its first publication in $2016,{ }^{28}$ the FAIR (findability, accessibility, interoperability, and reuse) data principles, on the other hand, have become a widely accepted guideline for research data management (RDM), emphasizing machine actionable data standards. Responsible RDM is the central theme of the International Science Council's Committee on Data (CODATA). ${ }^{29}$ Currently, a crossnational GO FAIR Initiative is building a network to advocate the FAIR principles through coordinating policy, technology, and awareness and skillbuilding activities. ${ }^{30}$

The scholarly communication revolution has started to touch the ethical core of scientific practice as well as its technical workflow-from open access, open data, and open science, to citizen science. Several national and international groups are working to coordinate open science and research data efforts, to align science with societal values and strategically plan for public access of data. ${ }^{31}$

Despite these developments, researchers seem slow to respond. The "State of Open Data Report 2019" revealed that although the majority of responding researchers support national and funders' open data mandates, FAIR data principles are still relatively unknown to them, primarily due to apprehensions about the misuse of openly shared data. ${ }^{32}$

Further development of RDS within academic libraries faces potential opportunities and practical difficulties, in light of this dichotomy. New studies based on North
American academic libraries ${ }^{33}$ and beyond ${ }^{34}$ reported a similarity of commitments and strengths: a majority of responding libraries' RDS are still an extension of the library's traditional advisory and training services. Of the libraries that offer advanced RDS, including training or assistance on data analysis, data visualization, and data integrity, most started the service in the last three years. Barriers to developing RDS include lack of resources (financial, staffing, and skills) and researcher engagement. The U.S. Data Curation Network examined 114 ARL institutions and reported that about $44 \%$ of them had a dedicated data repository, but information about data curation support is rarely available on these websites. ${ }^{35}$

A potential model to combat the resource obstacles in individual libraries involve collaborative data curation networks. The grant-funded Data Curation Network (DCN) project has developed extensive curation workflow and checklist resources, ${ }^{36}$ and the Canadian Data Curation Forum is designing a national data curation network based on the U.S. DCN model. ${ }^{37}$ The Greater Western Library Alliance found that most libraries with data repositories already have staff who assist researchers with creating metadata and data documentation. ${ }^{38}$

A National Library of Medicine workshop identified seven skill categories for librarians working in data science and open science, including computational ability and program and service development. ${ }^{39}$ As a result, many current data librarians will need more technical-intensive and advanced RDM training.

\section{Social justice, critical librarianship, and critical digital pedagogy}

Social justice and critical librarianship initiatives continue to gain momentum in academic libraries of all sizes. As described by Emily Drabinski, "Critical librarianship acknowledges and then interrogates the structures that produce us as librarians, our spaces as libraries, our patrons as students, faculty, and the public." ${ }^{40}$ It is grounded in "a librarianship that ... disrupt[s] the 
status quo, that center[s] a commitment to social justice and social change, ... . and that grapple[s] directly with the problems of power concentrated in the hands of a only a few." ${ }^{41}$

One study notes that, "The LIS classroom is where the values of LIS that are associated with social responsibility are introduced to future librarians, and by extension where the ability to create positive change begins." ${ }^{42}$ Another calls for librarians to design instruction that has the potential to highlight important social issues as well as better engage with students. ${ }^{43}$

Recent examples of critical librarianship and social justice at work in libraries span research and user services to areas of collections and technical services. ${ }^{44}$ When turned to digital tools, "critical digital pedagogy takes into account the limitations of any given technology and centers inquiry over technology. ${ }^{45}$ Librarians are applying these values to digital libraries ${ }^{46}$ and open pedagogy. ${ }^{47}$ Underlying all of this seems to be a vigorous emphasis on student agency and a resistance to corporate influence in higher education, especially from technology and publishing companies.

However, some have criticized the movement "for being inaccessible, exclusionary, elitist, and disconnected from the practice of librarianship." ${ }^{48}$

\section{Streaming media}

Streaming media has been an active and changing space in the past few years. Libraries are trying to figure out a responsible path forward that supports users' needs and expectations for selection and accessibility. With increasing support for online and hybrid courses, as well as flipped classroom pedagogy, ${ }^{49}$ the appeal and desirability of streaming content is clear.

Various articles document different components of these challenges-from acquisitions workflows, to pricing, to accessibility. Many libraries are updating and publishing their decision-making workflows for streaming media collection development, with ac- cessibility considerations forming a large piece of several libraries' decision trees. ${ }^{50}$ The accessibility license language used by the Big Ten may be of particular interest to those looking to conduct third-party evaluation for licensed content. $^{51}$

Kanopy is one of the largest and most written-about players in the streaming media market. Articles document public and academic libraries forays into licensing Kanopy content, only to end their agreements due to unsustainable costs. Lessons learned point to increased user education about pricing and the challenges of the patron-driven acquisition versus pay per use model often employed by public libraries. ${ }^{52}$ Various articles in the New York Times ${ }^{53}$ and Entertainment Weekly ${ }^{54}$ were touting it as just that-streaming movies for free through your library-without conveying the costs to libraries. A user education-directed post in Film Quarterly discusses the cost differences for consumer and institutional media pricing, encouraging film scholars and teaching faculty to be aware of how their choices impact others in the market. ${ }^{55}$

\section{Student wellbeing}

In recent years, a number of academic studies and news stories have reported on the rising rates of college students struggling with depression, anxiety, sleep deprivation, food insecurity, family responsibilities, and other factors impacting student wellbeing. For example, one study reported that the "percentage of all students nationally who reported being diagnosed with or treated for anxiety disorder climbed from 10 percent in 2008 to 20 percent in 2018" ${ }^{\prime 6}$ and another cited National College Health Assessment data showing approximately two-thirds of students report "overwhelming anxiety." ${ }^{57}$ One review suggests that college students are at increased risk of food insecurity compared to the general population..$^{58}$ Mary J. Wise reports that nearly half of college students indicated having "more than a little problem to a very big problem with sleepiness during daytime activities." 59

As a result, institutions are increasingly looking at supporting students holistically and promoting student wellbeing as possible con- 
tributors to their success and retention. Libraries are well-positioned to help, due to their central locations, longer operating hours, and perception as a safe space, with some stressing the importance of collaborating with campus partners, social service agencies, and professionals ${ }^{60}$

In order to promote mindfulness and support the mental and spiritual wellbeing of students, a number of libraries have created spaces and programs to meet this need, including meditation and prayer rooms, free yoga sessions, food pantries, and nap spaces. ${ }^{61}$

Studies have also discussed the increasing rates of autism spectrum disorder (ASD) and the need for colleges and libraries to support the wellbeing of a neurodiverse student population. ${ }^{62}$ Recommendations include implementing universally designed instruction, offering quiet spaces, providing space for autistic students to use their expertise to tutor others, offering chat reference for asking questions, and conducting campus outreach to raise autism awareness. ${ }^{63}$

\section{Final note}

This article was written well before the world was fully aware of the novel coronavirus that has since spread around the globe. As this issue of CERL News goes to press, institutions have closed their facilities and moved their classes online; vendors have opened up their collections on a temporary basis; and conferences have postponed or cancelled outright, along with many other changes in library operations. We anticipate that this situation will have long-lasting repercussions, very likely including massive budget cuts. Despite these uncertainties, libraries are positioned to provide online research and teaching support to patrons using virtual conferencing and other tools.

\section{Notes}

1. Mary Lee Kennedy, "Research Libraries as Catalytic Leaders in a Society in Constant Flux: A Report of the ARL-CNI Fall Forum 2019" (Association of Research Libraries and Coalition for Networked Information, January 2020): 18, https://doi.org/10.29242/report.fallforum2019.

2. Steven Bell, "Leading Though VUCA Times," Library Journal, September 28, 2017, https://www.libraryjournal.
com/?detailStory=leading-though-vuca-times -leading-library.

3. Ex Libris, "Ex Libris Signs Definitive Agreement to Acquire Innovative," Ex Libris, December 5, 2019, https://www.exlibrisgroup. $\mathrm{com} /$ press-release/ex-libris-signs-definitive -agreement-to-acquire-innovative/.

4. Roger Schonfeld, "What Are the Larger Implications of Ex Libris Buying Innovative?," Ithaka $S+R$, December 5, 2019, https://srithaka. $\mathrm{org} / \mathrm{blog} /$ what-are-the-larger-implications-of -ex-libris-buying-innovative/.

5. "FOLIO Platform \& Roadmap," FOLIO | The Future of Libraries Is Open, accessed January 20, 2020, https://www.folio.org/platform/.

6. National Information Standards Organization (NISO), "Flexible API STandard for E-Content NISO (FASTEN)," accessed January 10, 2020, https://groups.niso.org/apps/group _public/document.php?document_id=22568.

7. Gwen Evans and Roger C. Shonfeld, "It's Not What Libraries Hold; It's Who Libraries Serve: Seeking a User-Centered Future for Academic Libraries," January 23, 2020, https:// sr.ithaka.org/wp-content/uploads/2020/01 /OhioLINK_ILSUserCenteredFuture_1.23.20. pdf.

8. ACRL Research Planning and Review Committee, "2018 Top Trends in Academic Libraries: A Review of the Trends and Issues Affecting Academic Libraries in Higher Education," College \& Research Libraries News 79, no. 6 (2018), doi:https://doi.org/10.5860 /crln.79.6.286.

9. Megan Oakleaf, "Library Integration in Institutional Learning Analytics," LIILA White Paper (Syracuse University, November 18, 2018), https://library.educause.edu/resources /2018/11/library-integration-in-institutional -learning-analytics.

10. April Hathcock, "Learning Agency, Not Analytics," At The Intersection, January 24, 2018, https://aprilhathcock. wordpress.com/2018/01/24/learning-agency -not-analytics/.

11. "Data Doubles," accessed January 20, 2020, https://datadoubles.org/project/.

12. Kyle M. L. Jones, "Just Because You Can Doesn't Mean You Should': Practitioner 
Perceptions of Learning Analytics Ethics," portal: Libraries and the Academy 19, no. 3 (July 2019): 408, doi:10.1353/pla.2019.0025.

13. Jason Griffey, ed., "Artificial Intelligence and Machine Learning in Libraries," Library Technology Reports 55, no. 1 (January 2019), doi:https://doi.org/10.5860/ltr.55n1.

14. Thomas Padilla, "Responsible Operations: Data Science, Machine Learning, and $\mathrm{AI}$ in Libraries" (OCLC Research, December 8, 2019): 19, https://doi.org/10.25333/xk7z-9g97.

15. Sarah Pugachev, "What Are 'The Carpentries' and What Are They Doing in the Library?," portal: Libraries and the Academy; Baltimore 19, no. 2 (April 2019): 209-14, doi:http://dx.doi.org/10.1353/pla.2019.0011; Nancy K. Herther, "Library Carpentry: A Toolkit for Researchers," Information Today, April 2019, https://search.proquest. com/lisa/docview/2213034706/abstract /C6F7C1197F0940B2PQ/2.

16. Michael Hiltzik, "Column: In Act of Brinkmanship, a Big Publisher Cuts off UC's Access to Its Academic Journals," Los Angeles Times, July 11, 2019, https://www.latimes.com /business/hiltzik/la-fi-uc-elsevier-20190711 -story.html.

17. Elaine Westbrooks, "Update on Elsevier Negotiations from University Librarian Elaine Westbrooks," UNC University Libraries, December 11, 2019, https://library.unc. edu/2019/12/update-on-elsevier-negotiations/.

18. "Big Deal Cancellation Tracking," SPARC, accessed January 18, 2020, https:// sparcopen.org/our-work/big-deal-cancellation -tracking/.

19. UC Publisher Strategy and Negotiation Task Force, "Negotiating with Scholarly Journal Publishers: A Toolkit from the University of California" (University of California, May 2019), https://osc.universityofcalifornia.edu /uc-publisher-relationships/negotiating-with -scholarly-journal-publishers-a-toolkit/.

20. University of California, "Guidelines for Evaluating Transformative Open Access Agreements," University of California Office of Scholarly Communication Blog, accessed January 18, 2020, https://osc.universityofcalifornia. edu/uc-publisher-relationships/guidelines-for -evaluating-transformative-open-access -agreements/.

21. University of California Office of Scholarly Communication, "Guide to Transitioning Journals to Open Access Publishing" (University of California, 2019), https:// osc.universityofcalifornia.edu/wp-content /uploads/2019/02/UC-OSC-Guide-to-Transitioning -Journals-to-OA.pdf.

22. "Agreement Registry," ESAC: Efficieny and Standards for Article Charges, accessed January 17, 2020, https://esac-initiative.org/about /transformative-agreements/agreement-registry/.

23. Lisa Janicke Hinchliffe, "Transformative Agreements: A Primer," Scholarly Kitchen, April 23, 2019, https://scholarlykitchen.sspnet. org/2019/04/23/transformative-agreements/.

24. "Principles and Implementation | Plan S," COALition S, accessed January 31, 2020, https://www.coalition-s.org/addendum-to-the -coalition-s-guidance-on-the-implementation -of-plan-s/principles-and-implementation/.

25. Holly Else, "Ambitious Open-Access Plan S Delayed to Let Research Community Adapt," Nature, May 30, 2019, doi:10.1038 /d41586-019-01717-2.

26. SocPC TSPOA, "Bridging Learned Society Publishing and Open Access: An International Collaboration and Webinar Series," August 13, 2019, https://tspoa.org/2019/07/30/254/.

27. Elizabeth Ford et al., "Our Data, Our Society, Our Health: A Vision for Inclusive and Transparent Health Data Science in the United Kingdom and Beyond," Learning Health Systems 3, no. 3 (2019): e10191, doi:10.1002/ lrh2.10191; Bobby Lee Houtkoop et al., "Data Sharing in Psychology: A Survey on Barriers and Preconditions:," Advances in Methods and Practices in Psychological Science, February 15, 2018, doi:10.1177/2515245917751886.

28. Mark D. Wilkinson et al., "The FAIR Guiding Principles for Scientific Data Management and Stewardship," Scientific Data 3, no. 1 (March 15, 2016): 1-9, doi:10.1038 /sdata.2016.18.

29. Committee on Data, "CODATA's Mission-CODATA," CODATA's Mission, accessed February 6, 2020, http://www.codata.org/aboutcodata/our-mission. 
30. "GO FAIR," GO FAIR, accessed January 21, 2020, https://www.go-fair.org/.

31. Treasury Board of Canada Secretariat and Treasury Board Secretariat of Canada Open Government, "Canada's 2018-2020 National Action Plan on Open Government," accessed January 21, 2020, https://open.canada.ca/en /content/canadas-2018-2020-national-action -plan-open-government; "OpenAIRE," OpenAIRE, accessed January 20, 2020, https://www. openaire.eu/; National Academies of Sciences, Engineering, and Medicine, Open Science by Design: Realizing a Vision for 21st Century Research (Washington, D.C.: National Academies Press, 2018), doi:10.17226/25116.

32. Briony Fane et al., "The State of Open Data Report 2019" (Digital Science and Figshare, 2019), doi:10.6084/M9.FIGSHARE.9980783.

33. Carol Tenopir et al., "Research Data Services in Academic Libraries: Where Are We Today?" (ACRL/Choice, 2019), http://choice360. org/librarianship/whitepaper.

34. Andrew M. Cox et al., "Maturing Research Data Services and the Transformation of Academic Libraries," Journal of Documentation 75, no. 6 (January 1, 2019): 1432-62, doi:10.1108/JD-12-2018-0211.

35. Lisa R. Johnston and Liza Coburn, "Data Sharing Readiness in Academic Institutions" (Data Curation Network, January 15, 2020), https://datacurationnetwork.org/data -sharing-readiness-in-academic-institutions/.

36. Data Curation Network, "Data Curation Network-A Shared Staffing Model for Digital Data Repositories," accessed February 6, 2020, https://datacurationnetwork.org/.

37. "Canadian Data Curation Forum," accessed January 21, 2020, https://data-curation. github.io/.

38. Matthew Murray et al., "A Survey of the State of Research Data Services in 35 U.S. Academic Libraries, or 'Wow, What a Sweeping Question," Research Ideas and Outcomes 5 (December 27, 2019): e48809, doi:10.3897 /rio.5.e48809.

39. Lisa Federer, Sarah C. Clarke, and Maryam Zaringhalam, "Developing the Librarian Workforce for Data Science and Open Science," January 16, 2020, doi:10.31219/osf.io/uycax.
40. Emily Drabinski, "What Is Critical about Critical Librarianship?," Art Libraries Journal 44, no. 2 (April 2019): 49, doi:10.1017 /alj.2019.3.

41. Ibid., 51.

42. Davin Helkenberg et al., "Education for the Common Good: A Student Perspective on Including Social Justice in LIS Education," Journal of Education for Library and Information Science 59, no. 4 (October 1, 2018): 270, doi:10.3138/jelis.59.4.2018-0013.

43. Nicole A. Branch, "Illuminating Social Justice in the Framework: Transformative Methodology, Concept Mapping, and Learning Outcomes Development for Critical Information Literacy," Communications in Information Literacy 13, no. 1 (March 2019): 4-22, https://login.proxy006.nclive.org /login?url=http://search.ebscohost.com/login. aspx?direct=true \&db=1lf\&AN=138258256\&site $=$ ehost-live $\&$ scope $=$ site.

44. Heidy Berthoud and Rachel Finn, "Bringing Social Justice behind the Scenes: Transforming the Work of Technical Services," Serials Librarian 76, no. 1-4 (January 2019): 162-69, doi:10.1080/0361526X.2019.1583526.

45. Myra Waddell and Elena Clariza, "Critical Digital Pedagogy and Cultural Sensitivity in the Library Classroom: Infographics and Digital Storytelling," College \& Research Libraries News 79, no. 5 (2018), doi:https:// doi.org/10.5860/crln.79.5.228.

46. Digital Library Federation, "Digital Library Pedagogy," Digital Library Pedagogy, accessed October 3, 2019, https://www.diglib. org/groups/digital-library-pedagogy/.

47. Rajiv S. Jhangiani and Arthur C. Green, "An Open Athenaeum: Creating an Institutional Home for Open Pedagogy," in OER: A Field Guide for Academic Librarians, ed. Andrew Wesolek, Jonathan Lashley, and Anne Langley (Forest Grove, Oregon: Pacific University Press, 2019), 141-62, https://commons.pacificu.edu /cgi/viewcontentcgi?article $=1003 \&$ context =pup.

48. Karen P. Nicholson and Maura Seale, eds., The Politics of Theory and the Practice of Critical Librarianship (Sacramento, CA: Library Juice Press, 2018): 2. 
49. Andy Horbal, "Instructor Use of Educational Streaming Video Resources," The Journal of Academic Librarianship 44, no. 2 (March 1, 2018): 179-89, doi:10.1016/j. acalib.2018.02.009.

50. Mary Wahl, "Full Stream Ahead: Designing a Collection Development Workflow for Streaming Video Content," Library Resources \& Technical Services 61, no. 4 (October 2017): 226-36, doi:10.5860/lrts.61n4.226; Heidi M. Schroeder, "Implementing Accessibility Initiatives at the Michigan State University Libraries," Reference Services Review, August 13, 2018, doi:10.1108/RSR-04-2018-0043.

51. Schroeder, "Implementing Accessibility Initiatives at the Michigan State University Libraries."

52. Andrea Rodgers, "Once upon a Time in Streaming Video: A Community College's Adventure with Kanopy's PDA Model," College \& Research Libraries News, accessed October 3, 2019, https://doi.org/10.5860 /crln.80.8.498.

53. Glenn Kenny, "Unlocking Film Vaults With a Library Card," New York Times 166, no. 57709 (September 3, 2017): 8-8.

54. Maureen Lee Lenker, "What You Need to Know About Kanopy (No. 1: It's Free!)," Entertainment Weekly, no. 1546 (January 25, 2019): 40-40, http://search.ebscohost. $\mathrm{com} / \operatorname{login}$.aspx? direct=true $\& \mathrm{db}=\mathrm{a} 9 \mathrm{~h} \& \mathrm{AN}=134$ 173316\&site $=$ ehost-live.

55. Chris Cagle, "Kanopy: Not Just Like Netflix, and Not Free," Film Quarterly, May 3, 2019, https://filmquarterly. org/2019/05/03/kanopy-not-just-like-netflix -and-not-free/.

56. Will Kane, "Anxiety 'Epidemic' Brewing on College Campuses | University of California," April 22, 2019, https://www. universityofcalifornia.edu/news/anxiety -epidemic-brewing-college-campuses.
57. Mary Ellen Flannery, "The Epidemic of Anxiety Among Today's Students - NEA Today," NEA Today, March 28, 2018, http:// neatoday.org/2018/03/28/the-epidemic-of -student-anxiety/.

58. Aydin Nazmi et al., "A Systematic Review of Food Insecurity among US Students in Higher Education," Journal of Hunger \& Environmental Nutrition 14, no. 5 (September 3, 2019): 725-40, https://doi.org /10.1080/19320248.2018.1484316.

59. Mary J. Wise, "Naps and Sleep Deprivation: Why Academic Libraries Should Consider Adding Nap Stations to Their Services for Students," New Review of Academic Librarianship 24, no. 2 (April 3, 2018): 201, https://doi.org/10.1080/13614533.2018. 1431948.

60. Ian Godfrey et al., "Supporting Student Retention and Success: Including Family Areas in an Academic Library," portal: Libraries and the Academy 17, no. 2 (2017): 375-88, https://doi.org/10.1353/pla.2017.0023; Samantha G Hines, "Connecting Individuals with Social Services: The Academic Library's Role," Collaborative Librarianship 9, no. 2 (2017): 10, https://digitalcommons.du.edu /collaborativelibrarianship/vol9/iss2/8/.

61. Elizabeth Ramsey and Mary C. Aagard, "Academic Libraries as Active Contributors to Student Wellness," College \& Undergraduate Libraries 25, no. 4 (October 2, 2018): 328-34, https://doi.org/10.1080 /10691316.2018.1517433.

62. Amelia Anderson, "Autism and the Academic Library: A Study of Online Communication," College E Research Libraries 79, no. 5 (2018): 645-58, https://doi.org/10.5860/crl.79.5.645.

63. Rachel M. McMullin and Kerry R. Walton, Supporting Students on the Autism Spectrum: A Practical Guide for Academic Libraries (Santa Barbara: Libraries Unlimited, 2019). 